\title{
SOME CRITICAL ISSUES OF HUMAN CAPITAL ACCOUNTING IN THE PUBLIC SECTOR OF DEVELOPING STATES
}

\author{
Remi Chukwudi Okeke ${ }^{1, a^{*}}$, Adeline Nnenna Idike $2, b$ \\ 1 Department of Public Administration and Local Government, University of Nigeria Nsukka \\ ${ }^{2}$ Department of Public Administration and Local Government, University of Nigeria Nsukka \\ E-mail address: ${ }^{a}$ remiokeke@gmail.com, bojeleogbu@yahoo.com \\ *remiokeke@gmail.com
}

\section{Keywords: Human Capital Accounting, Public Sector, Developing States}

\begin{abstract}
This study examines the concept of human capital accounting as it relates to the public sector of developing countries. It interrogates the origin of the concept of human capital accounting. It studies what human capital accounting portends for the public sector in developing countries. It is a study of the relevance and the omens of human capital accounting in the public sector of developing countries. The public sector trajectory of human capital accounting is viewed in the study, as a peculiar tool of public (sector) administration in the developed societies and not a universally applicable tool of public administration at the current level of development in the developing states. Consequently, the study leads to a conclusion that in the public sector of developing states, human capital development or human capital formation may be the more relevant engagement for scholarship and practical purposes.
\end{abstract}

\section{INTRODUCTION}

The concept of human capital presents an engaging subject of interdisciplinary importance. Its most popular variants include human capital development and human capital theory. Another critical variant of the generic human capital concept is human capital accounting. The interdisciplinary weight of human capital accounting may be contestable. Nevertheless, it is a weighty concept all the same. Furthermore, most researches on human capital accounting are concentrated on the non-public sector. Accounting is frequently associated with business and profitmaking purposes. Human capital accounting is therefore easily associated with the formal accounting profession and accounting practices. However, human capital is not a peculiarity of business. Accounting also is not an oddity in the public sector. After all, there is public sector accounting. Invariably, human capital accounting is applicable to the public sector. We are in this study therefore, primarily interested in the meaning of human capital accounting and what the concept/practice portends for the public sector in developing countries. What is its relevance? What are the omens? Invariably, the theoretical framework of the study is the human capital theory. Our research methodology is logical argumentation.

\section{CONCEPTUAL ELUCIDATION}

Human capital accounting. Human capital accounting is indeed, a highly complex process and this complexity principally lies in the reality that there are hundreds of factors, which comprise an employee's value [1]. Nevertheless, let us properly commence this conceptual elucidation from the possible meaning of human capital. Thus, the human capital of an organization has been conceptualized as the collective sum of the attributes, life experience, knowledge, inventiveness, energy, and enthusiasm that its people choose to invest in their work [2,3]. It refers to the useful skills and knowledge acquired by people [4]. We underscore the issue of acquisition by people in this definition. It raises the question of ownership of human capital. In other words, in the face of the investments made by the individual on himself (before becoming member of a certain organization) and the subsequent and current investments being made on this individual by the organization (his current employers), who owns the resultant human capital? 
Human capital accounting, human asset accounting and human resource accounting are all synonymous concepts. Indeed, some authors [1,9] use these concepts interchangeably. In this study however, our choice of concept is human capital accounting. Credit for the origin of human capital accounting as a specific concept, is however, yet to be properly and convincingly attributed. Hence, in their highly cited work, Okpala and Chidi [5] argued that Theodore Schultz, the eminent American agricultural economist and extremely influential human capital theorist, first introduced human capital accounting in the 1960s. It appears however, as if what Schultz was the first to coin is the concept of human capital [4, 5, 11, 12]. According to Kern [11] Schultz, a Nobel prizewinning economist is credited with establishing the term, human capital. Moreover, after their initial statement that Shultz first introduced human capital accounting in the 1960s, Okpala and Chidi [5] further averred that Shultz (1961) originated the term Human Capital and in his later work in 1981, he elaborated on the concept by stating that all human abilities can be considered either innate or acquired. Furthermore, they (Okpala and Chidi [5]) argued that he (Schultz) referred to all attributes which can be augmented by appropriate investment, as human capital. Indeed, there is nothing easily identifiable in the work of Okpala and Chidi [5], which specifically refers to human capital accounting. Hence, additional research is required, in order to properly attribute the origin of human capital accounting (as a concept).

In any case, the American Association of Accountants defines Human Capital Accounting as a process of identifying and measuring data about human resources and communicating this to interested parties $[5,6]$. This particular conceptualization is immensely remarkable for our purposes (in this study). Despite emanating from a body of professional accountants, nothing in the definition has restricted its interpretative trajectories to either the core-business sector or the core-accounting profession. It is this process of identifying and measuring data about human resources and communicating this to interested parties, which we also conceive as human capital accounting in this study. The possibility of its application in the public sector is therefore not in doubt. The possibility of its misapplication in the public sector of developing countries is equally not in doubt.

Public sector / Public sector accounting. The public sector as a concept possesses some intriguing nuances. It is definable in simple terms as that section of an economic system that is under the control of government - the national, state, provincial or local government. However, according to The Institute of Internal Auditors [15] the term public sector can sometimes be ambiguous. In the opinion of the auditors, (in general terms), the public sector consists of governments and all publicly controlled or publicly funded agencies, enterprises, and other entities that deliver public programs, goods, or services. They further posit that it is not however, always clear, whether any particular organization should be included under that umbrella. Dzuke \& Naude [17] have even argued that the composition of public sector differs from country to country. Then according to Nashwa [18], public sector entities include state and local governments, federal agencies, public utilities, hospitals, colleges and universities, pension plans, city councils, boards of trustees (sic), legislatures and boards of governors (sic). Thus, we begin to see the evidence of ambiguities in the conceptualization of public sector.

However, we intend to avoid such ambiguities and intriguing conceptualizations in this study. Hence, we squarely use the concept of public sector in the study to distinguish between what governments do and what is done by profit-making organizations. By public sector, also, we specifically refer in this study to national aggregation and national aggregates (hoping that this is not ambiguous too). Consequently, reference to human capital account of the United States for instance, is illustrative of such national tendencies. On the other hand, public sector accounting invariably refers to the accounting practice(s) in government circles. Its objective is to improve the quality of information to a level at which it will reliably contribute to democratic decision-making [13].

Developing state(s). It has been succinctly remarked that when it comes to classifying countries according to their level of development, there is no criterion (either grounded in theory or based on an objective benchmark) that is generally accepted. Besides, that there are undoubtedly those who would argue that development is not a concept that can provide a basis upon which 
countries can be classified [14]. The issue of what constitutes development has accordingly remained an age-old debate (among development theorists and professional development practitioners of various disciplines). Development however is an issue on which relativism not only remains polemical but also often constitutes a distraction to what truly needs to be done. For instance, notwithstanding the number of airports in a particular country, and the model and numeric strength of aircrafts in the national carrier, if this country is also mosquito-infested and peopled by malaria-bedeviled nationals, it will not be plausible to classify such a country as either developed or even developing. But back to our major focus. In the context of human capital configurations, when is a state developed, underdeveloped or developing? In our views, a developed state is characterized by an abundance of human capital. We shall for the purposes of this study discountenance underdevelopment, which indicates stagnation, and focus on a developing state. Invariably, a developing state is that state which is characterized by the potentials for human capital abundance. In this instance, the complementary concept of human capital abundance does not merely allude to quantities but more pointedly refers to quality. It is indeed; this dearth of quality that often manifests as elite corruption in the developing states (as elite corruption easily fits into the notable features of developing states).

\section{CRITICAL ISSUES}

Research in human capital has experienced a resurgence over the past several years, with human capital accounts having been produced recently in Australia, Canada, China, Finland, New Zealand, Norway, Sweden, the United Kingdom, and the United States [7]. Christian [8] specifically presents a human capital account for the United States from 1994 to 2006. The attendant scenario is thus, indicative of a renascent trend in human capital accounting in the public sector of these states. We therefore contend that under the influence of globalization, we may soon begin to hear about the human capital accounts of Nigeria, Kuwait, Ghana, Pakistan, et cetera. However, human capital accounting in the public sector seems to be of better applicability in the environment of developed states. The critical question now is this: is human capital accounting a plausible tool of administration in the public sector of developing states? As a developing state trudges on (or swaggers up), its ultimate intention is to manifest the character of a developed society, which in this study conceptually includes a public sector trajectory of human capital accounting. Is human capital accounting in the public sector, a peculiar tool of public (sector) administration in the developed societies? Is it a universally applicable tool of public administration, irrespective of a country's developmental status? By way of analogy, budgeting is a tool of universal applicability in public sector management (public administration). Is human capital accounting also a tool of such universal applicability? We contend that the factors that make human capital accounting an unnecessary engagement in the public sector of the developing states include the following:

\section{- The unreliability of data from such developing states}

Intertwined with the issue of progress among the developing states is the unreliability of data that emanate from such states. Consequently, planning without facts [19] has remained a central developmental problem in these states. The problem of data in such states is actually, not so much about the absence of data but the fact of the unreliability of available data - the incidence of poor numbers [20]. This incidence of poor numbers is so pervasive that in the Nigerian (developing) state for instance, even state governments manipulate their school enrolment figures to get more money from the federally collected pool of funds [21]. The credibility of official statistics from developing countries has therefore remained in doubt. The questions that arise therefore border on what is to be done [20]. Invariably, human capital development/human capital creation should be embedded in what is to be done. Human capital accounting is not part of it, as it will be based on unreliable statistics emanating from lack of human capital. 


\section{- Attempting to build something on nothing}

Incidentally, the unreliability of data that emanate from the emerging states is symptomatic of human capital inadequacies. To rely on such data therefore for human capital accounting (by personnel of doubtful competencies) leads to nowhere in particular. It is tantamount to building something on nothing. Furthermore, using the rule of thumb, it is evident that there is an abundant lack of human capital among the developing countries. It is important to distinguish between labour (the supply of which may surpass demand among the developing countries) and human capital. In the face of this manifest dearth of useful skills and knowledge in the developing countries, human capital accounting in the public sector would amount to building something on nothing. Indeed, human capital accounting does not precede the abundance of human capital. In other words, the abundance of human capital is not a function of human capital accounting and what is needed in the developing states is an abundance of human capital. We argue that the essence of human capital accounting in the public sector (of developed states) is to channel surpluses to areas of deficiencies but in the developing states, the issue of surpluses of human capital (as distinguishable from human labour) currently remains out of consideration. There are no surpluses of human capital in the developing states.

\section{- The issue of commodification of labour}

In its expanded format, human capital accounting involves measuring the costs incurred by organizations to recruit, select, hire, train and develop human assets. It also involves measuring the economic value of people to the organisation [5]. In the public sector of developing states, this might translate to the commodification of labour [16]. In other words, it may in more worrisome manner, serve as justificatory tool for the commodification of labour, as the corrupt elite of the developing states grapple with the self-inflicted challenges that were even caused by their own greed. It is incontrovertible that people are the real wealth of a nation [10] but it is not by attributing costs to public sector personnel and assigning financial numbers to people that this commonwealth becomes established, particularly in the developing countries, with their human value challenges. This commonwealth is essentially created by an incidence of human capital abundance, not human capital accounting.

\section{- An ethical issue}

Arising from the issue of commodification of labour is an ethical issue relating to elite corruption in developing states. After the elite have blatantly mismanaged the resources of the state in such polities, human capital accounting may become a tool in the hands of the dubious elite to embark on downsizing and rightsizing, to the detriment of workers. In this case, human capital abundance is the casualty. It was principally the absence of human capital abundance, which led to elite corruption, which brought about the personalization and misuse of national resources. On what grounds would the corrupt elite rely on human capital accounting, to embark on personnel rationalization, downsizing and rightsizing?

\section{CONCLUSION}

In the public sector of developing states therefore, human capital development or human capital formation may be a more relevant engagement for scholarship and practical purposes. In clearer terms, what a developing state needs is more appropriately describable as human capital formation (human capital development for a developing state may raise the issue of development again?). Human capital formation entails a summative focus on the human capital needs of such a state because; human capital deficiency is among the fundamental indices of the dearth of development in the state. Scholarship and empirical engagements in developing states might as well focus on investments in human capital. Indeed, when the concept of human capital is trimmed to its concise meaning of useful skills and knowledge, possessed by people, it further becomes apparent that fundamentally, the adequacy of human capital accelerates the pace of development in every polity. Consequently, if the objective of public sector accounting is to improve the quality of information to a level at which it will reliably contribute to democratic decision-making, in the case of human capital formation, such democratic agreement should be taken for granted. 


\section{References}

[1] Stanko, B. B., Zeller, T. L., \& Melena, M. F. (2014). Human Asset Accounting and Measurement: Moving Forward. Journal of Business \& Economics Research (JBER), 12(2), 93-104.

[2] Weatherly, L. A. (2003). Human Capital - The Elusive Asset. Alexandria VA: Society for Human Resource Management.

[3] Jeroh, E. (2013). Human Capital Accounting and the Comparability of Financial Statements in Nigeria. Journal of Accounting Research and Management. 3(2), 53-64.

[4] Schultz, T.W. (1961). Investment in Human Capital. American Economic Review. 51(1), 1-17

[5] Okpala, P. O. and Chidi, O. C. (2010) "Human capital Accounting And Its Relevance To Stock Investment Decisions In Nigeria" European Journal of Economics, Finance and Administrative Sciences. Issue 21: 64-76.

[6] Rao, V.S.P. (2005).Human Resource Management: Text and Cases. (2nd ed). New Delhi: Excel Books

[7] Christian, M. (2011). Human capital accounting in the United States: Context, measurement, and application. Wisconsin Center for Education Research, Madison, USA.

[8] Christian, M. S. (2010). Human Capital Accounting in the United States: 1994 to 2006 (No. 0049). Bureau of Economic Analysis.

[9] Bokhari, I.H. et al. (2012). The yes, no decision is easy now: Is human capital accounting challenge for accountants? African Journal of Business Management 6(15), 5281-5287.

[10]United Nations Development Programme (1990). Human Development Report. New York: Oxford University Press.

[11]Kern, A. F. (2009). Human Capital Development Theory: Implications for Education Comparison of Influential Twenty-First Century Economists Samuel Bowles and Gary S. Becker. http://www.personal.psu.edu/afk119/blogs/career_tech_ed/2009/12/human-capitaldevelopment-theory.htm.

[12]Fitzenz, J. (2000). The ROI of Human Capital - Measuring the Economic Value of Employee Performance. New York: AMACOM.

[13] Tao, R. (2012). Public Sector Accounting - An Interdisciplinary Field Involving, Accounting, Economics, and Jurisprudence. Policy Research Institute, Ministry of Finance, Japan, Public Policy Review. 8(1), 45-66.

[14] Nielsen, L. (2011). Classifications of countries based on their level of development: How it is done and how it could be done. IMF Working Papers, 1-45.

[15]Dube, S. \& Danescu, D. (2011). Supplemental guidance: Public sector definition.Altamonte Springs, Florida: The Institute of Internal Auditors.

[16]Pocock, B, Prosser, R, \& Bridge, K. (2005). The Return of 'Labour-as-Commodity'? The Experience of Casual Work in Australia. Paper presented at the Reworking Work: AIRAANZ 05, University of Sydney, Sydney.

[17]Dzuke, A., \& Naude, M. J. (2015). Procurement challenges in the Zimbabwean public sector: A preliminary study. Journal of Transport and Supply Chain Management, 9(1), 1-9.

[18] Nashwa, G. (2005). The role of audit committees in the public sector. The CPA Journal, 75(8), 42.

[19] Stolper, W. F. (1966). Planning Without Facts: Lessons in Resource Allocation from Nigeria's Development. Cambridge: Harvard University Press.

[20]Jerven, M. (2013). Poor Numbers: How We Are Misled by African Development Statistics and What to Do about It. Ithaca, New York: Cornell University Press.

[21] Soludo, C. C. (2015). Can a new Buharinomics save Nigeria? Paper delivered at the 3rd Anniversary lecture of the RealNews magazine. Lagos, Nigeria: 19 November. 